\title{
Distribution of Pine Woolly Adelgids Infestation on Pinus merkusii Plantation in Java
}

\author{
Oemijati Rachmatsyah ${ }^{1 *}$, Ulfah Juniarti Siregar ${ }^{2}$, Noor Farikhah Haneda ${ }^{2}$, Dodi Nandika ${ }^{3}$, \\ Purnama Hidayat ${ }^{4}$
}

\author{
${ }^{1}$ Graduate School of Bogor Agricultural University, Dramaga Main Road, Campus IPB Dramaga, Bogor 16680, Indonesia \\ ${ }^{2}$ Department of Silvycultur, Faculty of Forestry, Bogor Agricultural University \\ Academic Ring Road, Campus IPB Dramaga PO Box 168, Bogor 16680, Indonesia \\ ${ }^{3}$ Department of Forest Product, Faculty of Forestry, Bogor Agricultural University \\ Academic Ring Road, Campus IPB Dramaga PO Box 168, Bogor 16680, Indonesia \\ ${ }^{4}$ Department of Plant Protection, Faculty of Agriculture, Bogor Agricultural University \\ Meranti Road, Campus IPB Dramaga PO Box 168, Bogor 16680, Indonesia
}

Received April 24, 2012/Accepted August 30, 2012

\begin{abstract}
Pine woolly adelgid is a recently found exotic pest attacking seedling up to grown plants of Pinus merkusii plantations forest. Since its discovery, there were not much information about it. The objectives of this research were to study pine woolly adelgids distribution, symptoms and indicators, and its scale of infestations on Pinus merkusii plantation in Java, to determine the presence of any specific P. merkusii sites invaded by pine woolly adelgids, considering the pests were native to boreal and temperate areas. Hypothesis was pine woolly adelgids infestation on P. merkusii in Java is consistent with their native distribution. There were 9 Forest Management Unit (KPH) with infested P. merkusii plantations which were located at altitude between 900 to 1,700 $\mathrm{m}$ asl. with temperature ranging 16-22 ${ }^{\circ} \mathrm{C}$ and air humidity 80-90\%. This indicated that Pine Woolly Adelgids required low temperature to survive, which was consistent with their original distribution. Host preference with regard to scale of infestation was closely related to temperature, altitude, and number of trees per hectare. The scale of infestation varied among regions, from light to heavy infested/death of trees.
\end{abstract}

Keywords: pine woolly adelgid, Pinus merkusii, scale of infestation, host preferences

*Correspondence author, email: oemijati1947@yahoo.co.id, telp.+62-251-8626806

\section{Introduction}

P. merkusii in Java Island is a superior plant for the StateOwned Forestry Enterprise (Perum Perhutani), with a total plantation area reaching 853,809 ha, where 232,853 ha distributed in Unit III of West Java and Banten, 303,038 ha in Unit I of Central Java and 317,918 ha in Unit II of East Java (Perum Perhutani 2009).

Forest plantations are generally grown in monoculture as the case for $P$. merkusii. Such condition according to Tarumingkeng (1984) and Husaini et al. (2007) will lead to increased plant vulnerability to pests, diseases, and forest fires. Kalshoven (1981), Supriana and Djatnika (1987), and Husaini et al. (2007) mention a few pests of $P$. merkusii in their native range: Melionia basalis, Cryptothelea variagata, Nesodiprion biremes attacking pine needles, Coptotermes curvignathus, C. travians, Dioryctria rubella attacking stems and roots. Nevertheless, these pests are categorized harmless to pine stands (Husaini et al. 2007). However, in 1997, a pest was found to attack pine plantations of West Manglayang Sub Forest Distrik (BKPH), North Bandung Forest District (KPH) causing death of trees aged 30 years/mature forest stands with relatively wide expanse. In
2001, the pests were reported to have attacked $P$. merkusii stands in West and East Pekalongan KPH and by 2003 it had spread to Surakarta KPH and Lawu Ds KPH attacking over 2,000 ha.

In 2006, this pest infestations were reported to have reached a total of 6,000 ha (including $11 \mathrm{KPH}$ ), attacking all age plant forms from nursery to mature plants. This insect was considered exotic, since prior to 1997 , there were no reports about their presence both in Indonesia as well as in neighbouring countries (Kalshoven 1981; Hutacharem \& Tubtim 1995; Nair 2001; Dieckman 2002). Therefore, the life of this insect is yet unknown in Indonesia. The local name given by the local officials was pine woolly adelgids. Identification by Dr Gillian W. Watson (2007) shows that these insects belong to genus Pineus, species boernerii, family Adelgidae, and order Hemiptera. Chillima and Leatheart (2001) found that the insect has a host range of over 50 species of exotic pines in Malawi, which resulted in the disruption of tree growth. While Lazzari and Josiane (2011) mentioned that $P$. boernerii has attacked various types of pines in Brazil and is the first species from Adelgidae family that has been recorded to occur in Brazil. Petro and Madoffe 
(2011) state that this insect is a threat to the native pines of Tanzania, $P$. oliotii and $P$. patula, where there was no difference between the 2 attacks.

The objectives of the research were to:

1 Identify the temperature, humidity and growth altitude of the host plant $P$. merkusii

2 Analyze the distribution of pine woolly adelgid sinfestations on P. merkusii plantation forests of Java

3 Analyze the factors that influence the attacks of pine woolly adelgid on P. merkusii

4 Identify the distribution of pine woolly adelgids according to the level of damage.

This study provides data and preliminary information on the conditions of the host plant growth area, level of damage, symptoms, and signs of pine woolly adelgids, to be considered in forest management to avoid/minimize the adelgids attacks. In addition, as consideration in conducting further research on bio-ecology of pine woolly adelgids to produce an effective and efficient pest control.

\section{Methods}

The research was conducted on $P$. merkusii plantation forests in Java Island that had been infested by the pine woolly adelgids (9 KPH), from August-December 2011. Instruments used in this research include mercury thermometer, hygrometer, GPS, binocular, ladder, cleaver, phi band, and Haga meter. Data collected comprised of:

1 The extent, location, age class of infested P. merkusii stands.

2 Temperature, humidity, and growth altitude of the infested pine stands.

3 Symptoms, signs, and level of infestations on the pine stands.

4 Management practices that are applied on the infested area especially with regard to pest control.

Secondary data on pine woolly adelgids infestation on $P$. merkusii forest were gathered from central office, office units, and KPH offices to acquire preliminary data on the location, area, age class, and measures to control and manage forest infested by the woolly adelgids. Data collected were then tabulated to select and determine sample plots for field data collection (signs and symptoms of the infestation, scale of infestation, temperature, humidity, and growth altitude of the areas infested by the adelgids). Sample plots were determined using purpossive sampling, with a sampling intensity of $1 \%$, the total area of sample plot is 0.1 ha.

Temperature and humidity were measured using mercury thermometer and wet-dry bulb thermometer on each predetermined sample plot. Temperature measurements were carried at 3 horizontal points with a distance of $50 \mathrm{~m}$ between each thermometer at a height of $120 \mathrm{~cm}$ above soil surface between 12:00 to $14: 30 \mathrm{pm}$. Observations were made every half hour. Data on growth altitude for each affected area was conducted only once. Data on the infestation rate, symptoms, and signs were obtained through direct observation of tree condition on each sample plot. Data on management practices were obtained by conducting interviews with field staffs and review existing reports.

Analysis of the relationship between environmental variables which are suspected to affect the infestation rate was performed using Pearson coefficient correlation. Analysis of the correlation between variables was then performed using SPSS V16.

The next step was to conduct collinearity test to identify a correlation between the independent variables used in the regression analysis. The best predictor variables to be use in regression models were the independent variables. A variable is considered dependent if other variables have a correlation coefficient $(r) \geq 0.80$. Multicollinearity can also be determined by the value of tolerance or the variance inflation factor (VIF) value. If a variable has a value of VIF $\geq$ 10 or $\leq 0.10$, then such variable is considered dependent or correlated with other variables. The relationship between VIF value with tolerance value and correlation coefficient is as equation [1]:

$$
V I F-\frac{1}{\text { Tolerance }}=1-r^{2}
$$

Variables having VIF value $\geq 10$ were not used in the subsequent regression analysis. In addition, principal component analysis (PCA) was performed to determine the variables having strong relation to the level of stand damage due to pine woolly adelgids infestation. Variables that could be used to explain the influence of all environmental variables on the level of damage if such variable has a value of Kaiser-Meyer-Olkin $(\mathrm{KMO}) \geq 0.50$ and each variable has a Measure of Sampling Adequacy value (MSA) $\geq 0.50$. Multiple regression analysis was conducted to determine the most influential variable of all observed variables (temperature, humidity, altitude, and number of trees $\mathrm{ha}^{-1}$ ). The correlations of the scale of damage due to the pest infestation on pine stands, with environmental variables were analyzed using multiple regression analysis.

Data on daily humidity were transformed into arcsin $=$ $\sqrt{\mathrm{RH} \%}$, while data on the number of trees and altitude above sea level were transformed into the natural logarithm (Ln). The tested hypothesis was: $\mathrm{H}_{0}: \beta_{\mathrm{i}}=0$, i.e. there was no correlation between the level of pest infestation with environmental variables, and as an alternative $\mathrm{H}_{1}: \beta_{\mathrm{i}} \# 0$, i.e. there was at least one environmental variable related to the level of pine woolly adelgids infestation on Perhutani pine stands.

\section{Results and Discussion}

There were $9 \mathrm{KPH}$ with infested pine stands by Pineus boerneri (Hemiptera: Adelgidae) (Watson 2007) distributed on Unit I, II, and III (KPH of West Pekalongan, East Pekalongan, Surakarta, Lawu Ds, Kediri, Jombang, Probolinggo, North Bandung, and Sumedang (Figure 1). Infested stands were located on areas with temperatures between $16-22{ }^{\circ} \mathrm{C}$, with humidity between $80-90 \%$, and an altitude of $900 \mathrm{~m}$ asl. The infested age class ranged from age class I-II including those in nurseries (Sumedang, Madison, Kediri, and Lawu) and seed orchard (KPH Sumedang). The scale of infestations ranged from light to heavy attack, ranging from $25-100 \%$ (Appendix 1 ).

The determinant factors for the attack were average daily temperature, daily air relative humidity, density of trees $\mathrm{ha}^{-1}$, and growth altitude. If sorted based on the scale of the 
infestations, the most influential were the average daily temperature followed by daily average air humidity, planting space, and growth altitude. Daily average temperatures correlated with growth altitude. Results of the analysis were presented in Appendix 2.

Research results also indicated that there was specific characteristics of the place to grow, which the host preferred such as relatively low daily average temperature $\left(16-22^{\circ} \mathrm{C}\right)$, high humidity (80-90\%) and growth altitude ( $>900 \mathrm{~m}$ asl). This signified that currently pine woolly adelgids were able to thrive in the tropics/Java, Indonesia, but was still limited to areas with low temperatures, high humidity with growth altitude $>900 \mathrm{~m}$ asl (Figure 2).

It was assumed that the reason was an initial adaptation to the tropical region being a region that is always warm (Ceisla 2011) compared to the insects native distribution which were temperate and boreal regions that experienced winter/snow. Carter (1971), Chillima and Leartheart (2001), Havill and Robert (2007) also state that P. boerneri is an endemic insect of temperate environment. Basically P.boerneri have

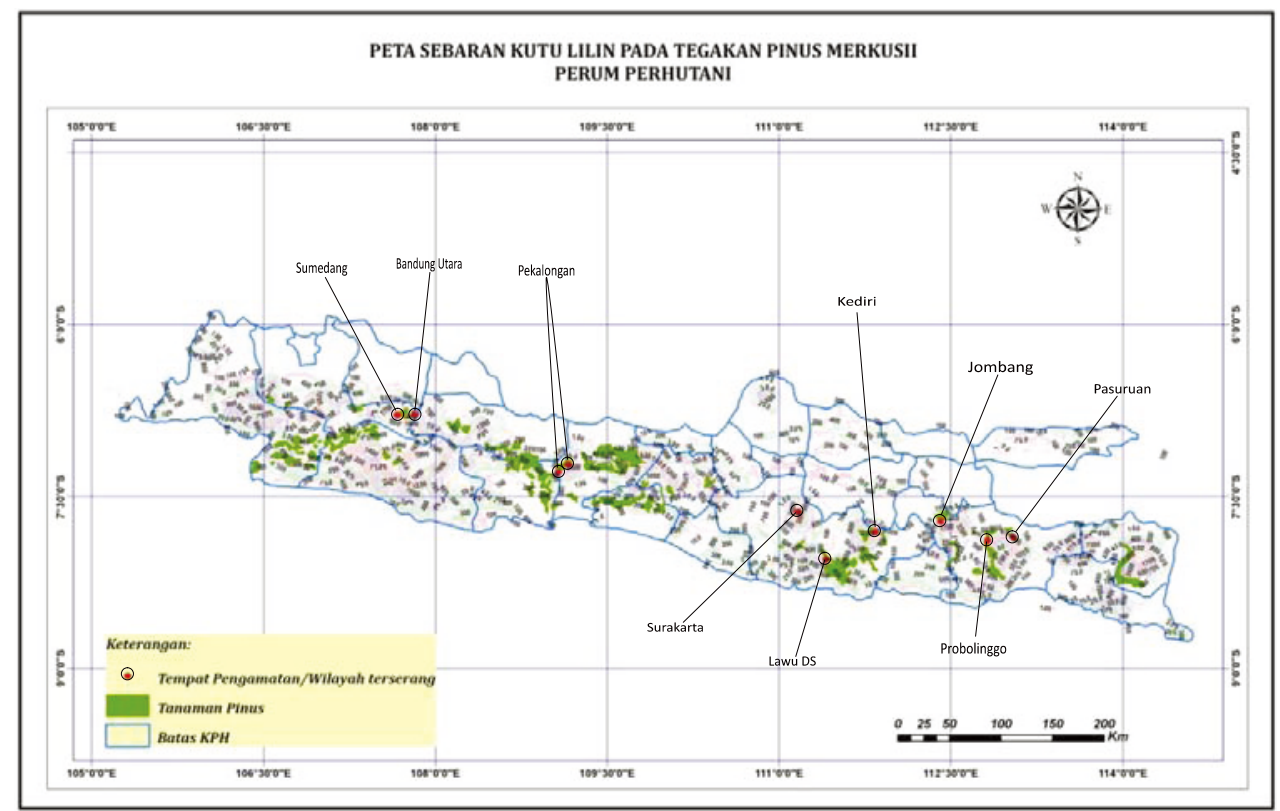

Figure 1 Distribution of pine wolly adelgids infestation on P. merkusii.

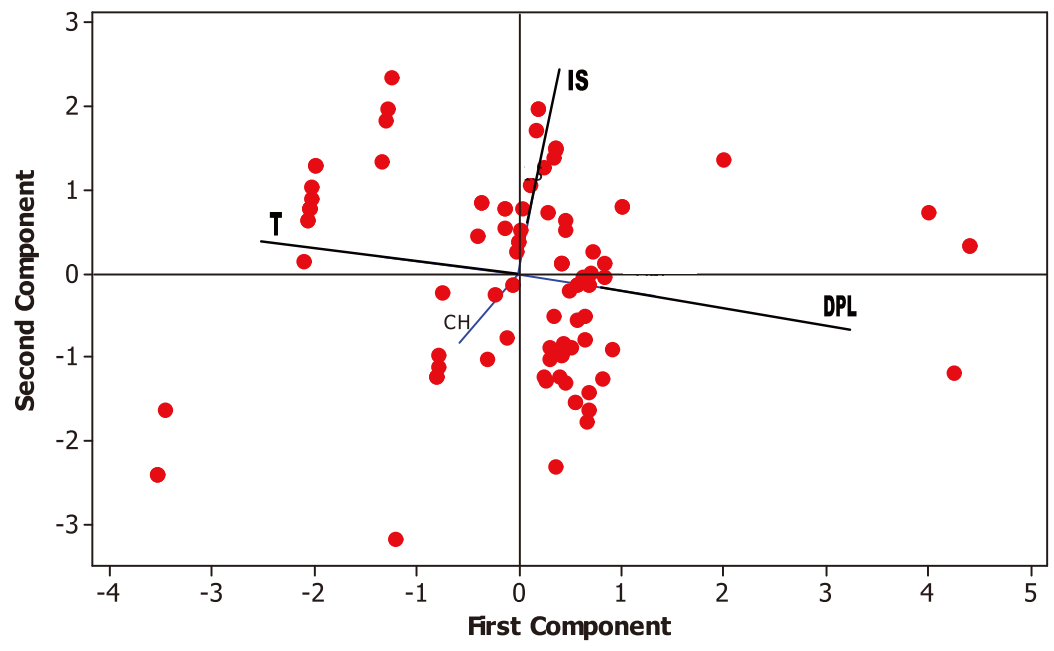

Figure 2 Rotation characteristic of the place with the quantities of attack. 
attacked the pine stands of tropical region such as in Brazil and was categorized as a new species attacking the pine stands there (Lazzari \& Josiane 2011). Petro and Madoffe (2011) mentioned that $P$. boerneri also attack native pine plantations of Tanzania/P. oliotii and P. patula.

Chillima and Leartheart (2001) mention that this insect was introduced to Africa and are threats to many exotic pine species there. The insects' attacked on Pinus kesya reduced tree growth up to $5 \%$. The insect life stages were related to total rainfall and the structure of tree canopy. Havill and Robert (2007) mention that the main host of this insect was the family Picea such as spruce and tsuga while hosts of both trees were various kinds of pine from family Pinaceae. Similarly, Yang and Shanchun (1997) also stated that this insect has 2 hosts, namely Picea and Pinaceae. The Pinaceae favour trees with 2 or 3 needles (Carter 1971). P. merkusii is one species of family Pinaceae which is native to Indonesia and spreads up to 2 der L.S. (Mirov 1967) is a species of pine with 2 needles showing prolonged infestation by the woolly adelgids (detected in 1997 and continues to this day). It is expected that this was due to the extensive pine plantations in Java, which has reached an area of 850,000 ha or more (Fachroji 2010), grown in areas with altitude of $500 \mathrm{~m}$ asl, planted in monoculture. This would provide abundant food and a good breeding place for the pine woolly adelgids, forming a threat/becoming pests to $P$. merkusii stands and reducing the ecological, economical, and social functions of P. merkusii plantations.

Coulson and Witter (1984) stated that $P$. boerneri favour plants with coarse fissured barks, conditions found in $P$. merkusii. However, field observation to learn more about the symptoms, signs, and distribution of this pest showed that pine woolly adelgids prefer tree tops/plant growth area and the axillary leaves with no preference on the infested parts, and later the infestation spreads to the bark and would settled located in the slit of the skin (Figure 2). This was more common in mature plants (age class 2 and above). Shoots were mainly infested because such part of the plant is still soft and relatively easier for the pest to inject its stilet.

Havill and Robert (2007) state that $P$. boerneri is the most destructive introduced insect threatening the forest ecosystems of North America. This situation is analogous to what was happening in Indonesia where this pest was also introduced and spread relatively quickly. The infestation is quite disturbing because it caused abnormal tree growth, death of shoot, and even tree death damaging the forest ecosystem of $P$. merkusii and reducing/disrupt the function of $P$. merkusii forest which for Perhutani is a superior plant after teak because pine has several advantages over teak, namely deep rooting (Suhendi (2007)/protection function, producer of wood and sap (Pandit \& Ramdan 2007)/production function and involvement of community in tapping sap/social function. Damage of pine forests implied reduced forest functions. Therefore, knowledge of the host's growth place was necessary to be considered in forest management, especially for pest control purpose. In Indonesia, pines are planted at an altitude of $500 \mathrm{~m}$ asl, where parts are categorized as protection forests. Pest control on protection forest is more complicated since such forest is intended for water catchment purposes which are very much required by various life support systems, hence pest control should be environ-mentally friendly.

The insects' attacks were indicated by symptoms where the needles turned yellowing, abnormal plant growth (dwarf) and more branching, die back and tree mortality. Signs of attack were very easy to detect through the presence of fine short threads covering the infested plants and if peeled, a colony of pine woolly adelgids could be seen (Figure 3 ). Scale of infestations was shown by the death of trees, brown leaves (Figure $4 \mathrm{~A}$ ) and exfoliation (Figure 4B). Direct field observation showed that there were 5 stages of infestations, namely early, light, moderate, heavy and severe (very heavy) (Table 1) both for age class young and mature stands (Appendix 1).

Schoonhoven et al. (2005) state that insects and plants are very closely related. Quantitatively, they are globally widespread both in the amount of biomass and abundance of

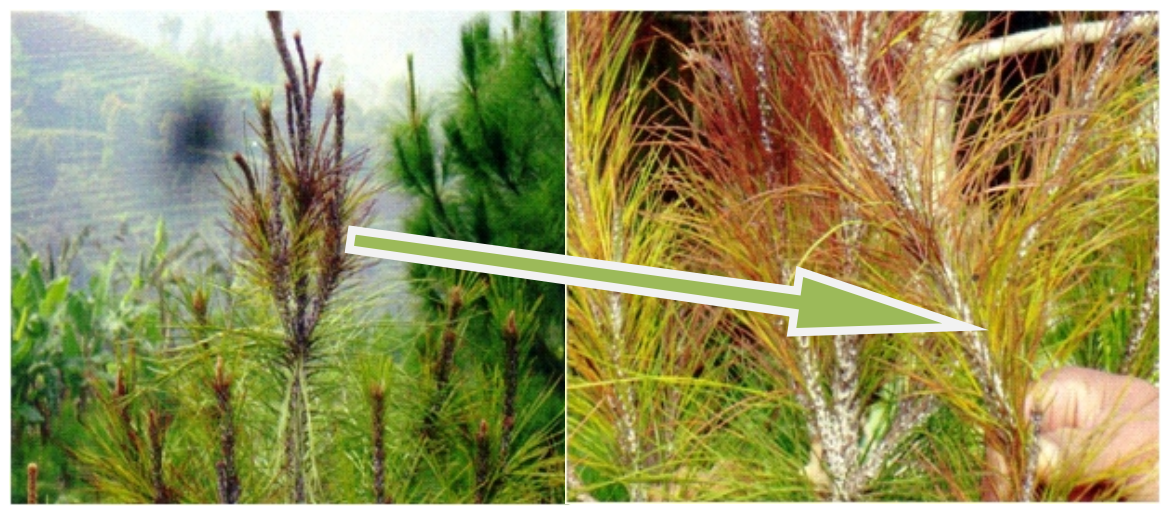

Figure 3 Tree tops of P. merkusii infested by P. boerneri shown by the presence of wax coating on the infested part (KPH Kediri) 
species, particularly insects which have an abundant number of species. Schowalter (2006) mentions that insects have the largest number of living organism species, which are generally herbivores. Based on these two statements, it can be said that the life of phytophagous insect is very much influenced by the life of its host plant. P. boerneri is a specialist insect in choosing its host plants, and in decidingthe host, the information is narrow and very specific, however, once it meets the host, it would develop well and become a threat/pest for the infested plant. Such was the case found in P. merkusiias the host for P. boerneri.

In obtaining food, $P$. boerneri/pine woolly adelgids inserted their piercing-sucking mouth parts into the infested plant and removing the plant fluids. In general, this insect infestation was considered less harmful if compared with insects consuming leaves and stems, although there are some species of Himeptera that could cause death of forest stands such as Aldegespiceae that attacked balsam plants and threatening to the plant (Coulson \& Witter 1984). Similar case occurred in $P$. boerneri where the insect proved to reduce the growth of Pinus kysea around 5\% (Chillima \& Learthert 2001). In Java, repeated pine woolly adelgids attacks had caused abnormal growth and even death of trees, especially during the early growth of trees. Early growing plants (age class I) generally suffered death after 2 years from the initial attack. This death was the result of dehydration of the plants which would impede the photosynthesis process (Hamim 2007). While mature plant death usually occurred after a long attack ( $>5$ years).

Insects are affected by several factors in finding their hosts such as for Homoptera; Aphididae that favoured yellow green colour (Larry 1996). P. merkusii is one of the family Pinaceae, native to Indonesia, has a special cone-shaped canopy with green colour which made it very easy to distinguish from other species (Mirov 1967). Siregar (2000) states that $P$. merkusii grow well in areas with an altitude 500-2,000 $\mathrm{m}$ asl, although it can also grow well on altitude 200-2,500 m asl. Apparently the pine woolly adelgids infestations were only confined on $P$. merkusii stands that grew on altitude higher than $900 \mathrm{~m}$ asl, with temperatures $16-22{ }^{\circ} \mathrm{C}$ and humidity $80-90 \%$ (Table 2 ). This suggested that $P$. boerneri which originated from temperate and subtropical regions were capable of associating with the tropics, although in areas with relatively low temperature. It also demonstrated the effects of temperature and altitude on the scale of the infestations (Table 2). The number of trees per

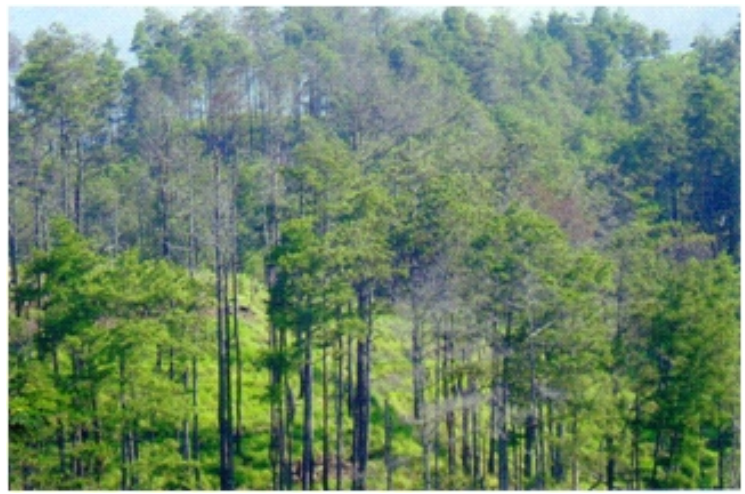

A

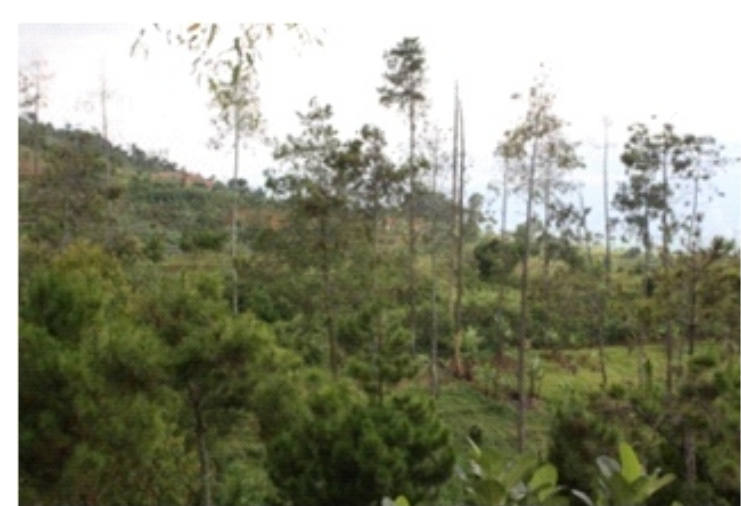

B

Figure 4 Picture of the infested pine stands (A), heavily infested pine stands (B).

Table 1 Criteria of $P$. boerneri infestations

\begin{tabular}{lcc}
\hline \multicolumn{1}{c}{ Conditions of tree } & Criteria of attack & Value \\
\hline $\begin{array}{l}\text { Healthy trees, no signs of attack, no wax layer, trees } \\
\text { having fresh green colour }\end{array}$ & No attack & \\
\hline $\begin{array}{l}\text { The attack has not reached 25\% of the tree tops, and some } \\
\text { parts of the leaves started to turn yellow, a layer of wax evently } \\
\text { distributed on affected parts of the branch. }\end{array}$ & Light attack \\
\hline $\begin{array}{l}\text { Parts of infested trees has reached 50\% of the tree tops, leaves } \\
\text { begin to turn yellow and partly brown, waxy coating covering } \\
\text { the affected part }\end{array}$ & Moderate attack \\
\hline $\begin{array}{l}\text { The attack has reached }>80 \% \text { of tree tops, buds die back, } \\
\text { brown leaf, waxy coating has reached the trunk }\end{array}$ & Heavy attack \\
\hline Tree die back, bare, and peeled skin & Severe attack \\
\hline
\end{tabular}


hectare also affected the attacks. This occurred since infestations were easily spread. The number of trees per hectare also indicated tree density, hence the denser the trees are, the easier it is for the pests to invade especially with the occurrence of wind.

Diekman et al. (2002) states that small sized insects can pose a great risk when finding the appropriate host at a new location, especially from the order Homoptera (Aphids, Mealbug, and other scaly insects). These insects generally attacked the top parts of the tree of which are the growing parts of the plant. This according to Deikman et al. (2002) has been well documented in North America, but not in other areas. $P$. boerneri has attacked more than 6,500 ha of pine plantations in Indonesia relatively quick. This was possible since $P$. merkusii plantations were planted in monoculture with relatively similar age, and quiet common environmental conditions, especially with regard to temperature and humidity. These are crucial elements of an insect's life. Insects are animals that are poikilotherm where body temperature is influenced by the temperature of their surrounding environment and is very influential on the development, growth, and geographic distribution of the insect (Schowalter 2006). P. boerneri that is originated from temperate areas found a host in tropical area that grew in areas with relatively low temperatures. This in turned provided abundant food which enable $P$. boerneri to multiply rapidly and spread throughout $P$. merkusii plantations on regions with relatively low temperature $(P$. boerneri are highly adaptive to cold temperatures (Carver 1996; Chilima \& Leatheart 2001; Yang \& Chanshun 2006).

The insect growth rate was expected to be influenced also by season. Indonesia has two seasons, the dry and the wet seasons with relatively small changes in temperature and relative humidity, that would lead to no dormancy of the insects and proliferation occurred continuously. Such conditions were also due to the fact that $P$. boerneri life on the second host was Parthenogenetic off spring.

Recognizing the symptoms and signs of pests is important. With those 2 indicators, field workers could quickly find the attack and immediately implement control. Symptoms of pine woolly adelgids attacked were leaves turning yellow, die back, dwarfing tree tops, tree mortality, and flaking bark. These indicators were basically not sufficient to determine whether a tree has been attacked by $P$. boerneri since there were many other confounding factors that have similar symptoms to $P$. boerneri attacks. Therefore, it must be followed with checking for signs of attacks, which are very easy to recognize from the presence of a layer of white, short fine yarn, covering the infested parts and when peeled, very small sized pine woolly adelgids could be observed.

Insects and host plants have a dynamic relationship due to the environmental influences as well as time (Price 1987). Schoonhoven et al. (2005) states the two important things in plant-insect interaction, i.e. what can be provided by the plants for the insects and how the insects got their needs. The two would result in two dynamics, self preservation of the plants and ways of obtaining life necessities of the insects. For sap sucking insects, after the discovery of their host plants, the insects would star the attacks which were supported by sensors located in the rear of the mouth in order to detect the presence of food. Pines are softwood, grow well at altitude $>500 \mathrm{~m}$ asl, have a coarse, and thick and fissured skins. Coulson and Witter (1984) mentioned that P. boerneri favour plants with rough fissured bark which aid in sustaining the insects' life.

P. boerneri (Hemiptera; Adelgidae) first attack was discovered in 1997 and continued to expand, and by 2009 it has attacked over 6,500 ha of pine stands in Java Island, in particular P. merkusii which is native to Indonesia (no pine woolly adelgids attacks have been recorded on other exotic pine species which in Indonesia such as $P$. oocarpa and $P$. caribea). Looking at the outer appearance, barks of $\mathrm{P}$. merkusii were more rough and grooved. Such conditions according to Coulson and Witter (1984) are favoured by these pests, since it will be easier for the insects to avoid confounding factors as well as weather changes under such conditions.

\section{Conclusion}

It was found that $P$. boerneri only attacked P. merkusii stands that grew on altitude $>900 \mathrm{~m}$ asl, with temperature $16-22{ }^{\circ} \mathrm{C}$ and humidity $80-90 \%$ a specific host plant growth place. These pests attacked all age levels, ranging from nursery to mature plants forms (KU I-VII), as well as those in seed garden. The level of attacks ranged from mild to severe/death of plants with an percentage attacks between 25-100\%. Attacks were very easy to recognize with reference to the symptoms and signs of the attack indicated by a change in colour on tree tops/yellow tree tops, dieback, death of trees and the presence of white yarn covering parts of affected trees. Control effectiveness can be done by conducting periodic monitoring to detect any early signs and symptoms of attack to perform immediate control.

\section{References}

Carter CI. 1971. Conifer wooly aphid (Adelgidae) in Britain. Forestry Commission Bulletin No. 42. London: Her Mayesty's Stationary Office.

Carver M, Gross GF, Woodward TE. 1996. Hemiptera (bugs, leafhoppers, cicadas, aphids, scale insect etc). The insect of Australia Vol. I. Division of Entomology. Commonwealth Scientific and Industrial Research Organization. Melbourne: Melbourne University Press.

Ciesla WM. 2011. Forest Entomology A Global Prespective. Wiley-Blackwell: A John Wiley \& Sons. Ltd. Publication. http://dx.doi.org/10.1002/9781444397895.

Chillima CZ, Leatheart SR. 2001. Within-tree anseseonal distribution of the pine wooly aphid Pineus boerneri on Pinus kesiya trees. Forestry Reseach Institute, Departement Biology Imperial Collage, Silwood Park UK.

Coulson RN, John AW. 1984. Forest Entomology, Ecology and Management. New-York: John Willey \& Sons.

Diekmann M, Sutherland JR, Nowell DC, Moraless FJ, 
Allard G. 2002. Pinus spp. Technical Guidelines for The State Movement of Germplasm No. 21. FAO/IPGRI. Rome: FAO/IPGRI.

Fachroji A. 2010. Model daya saing produk gondorukem di pasar internasional dan implikasinya terhadap pengembangan industri gondorukem di Indonesia (dissertation). Bogor: Graduate School of Bogor Agricultural University.

Graham SA, Knight FB. 1967. Principle of Forest Entomology. New-York. St Louis. San Fracisco. Toronto. London. Sydney: McGraw-Hill Book Company.

Hamim. 2007. Fisiologi Tumbuhan. Jakarta: Universitas Terbuka.

Havill NP, Robert GF. 2007. Biology and evolution of Adelgidae. The Annual Report Research of Entomology, 25:325-349. http://dx.doi.org/10.1146/annurev.ento. 52.110405.091303.

Husaeni EA, Kasno, Haneda NF, Rachmatsyah O. 2006. Pengantar Ilmu Hama Hutan di Indonesia Bio-Ekologi dan Teknik Pangendalian. Bogor: Department of Silviculture Faculty of Forestry IPB.

Hutacharem C, Nopachon T. 1995. Checklist of Forest Insect in Thailand. Bangkok: Office of Environmental Police and Planning.

Kalshoven LGE. 1981. The Pest of Crops in Indonesia. Jakarta: PT Ichtiar Baru-Van Hoeve.

Lazzari SMN, Josiane TC. 2011. Pineus boerneri Annand, 1928 (Hemiptera,Adelgidae)-a new species to Brazil: morphology of eggs, nymphs and adult. Revista Brasileira de Entomologia 55(4). http://dx.doi.org/10. 1590/S0085-56262011000400001.

Mirov NT. 1967. The Genus of Pinus. New York: The Ronald Press Company.

Nair KSS. 2001. Pest Outbreak in Tropical Forest Plantations: Is There a Greater Risk for Exotic Tree Species. Bogor: Center for International Forestry
Research.

Nair KSS. 2000. Insect Pest and Deseases in Indonesia Forest. An Assessement of The Mayor Threats, Research Efforts and Literature. Bogor: CIFOR.

Petro R, Madoffe SS. 2011 Status of Pine Woolly Aphid (P. boerneri) in Sao-Hill Forest Plantation, Tanzania. Morogoro: Tanzania Forestry Research Institute.

Price PW. 1987. Insect Ecology. Department of Biological Tucson: Wiley-Inter Science Publication.

Pusat Litbang Perhutani. 2008. Data Rekapitulasi Kawasan Hutan Pinus Terserang Hama Kutulilin. Cepu: Pusat Litbang Perhutani Cepu.

Schoonhoven et al. 2005. Insect Plant Biology. Laboratory of Entomology, Wageningen University. The Nederlands: Oxford University Press.

Schowalter TD. 2006. Insect Ecology, an Ecosystem Approach. San Diego: Academic Press.

Siregar IZ. 2000. Genetic Aspect of the Reproductive System of Pinus merkusii Jungh et de Vriese in Indonesia. Gottingen: Curvillier Verlag.

Steel RGD, Torrie JH, Dickey DA. 1981. Principles and Prosedure of Statistics: A Biometrical Approch. International Student Edition. New York. Mc. GrawHill.

Tarumingkeng RC. 1984. Manajemen Hama pada Hutan Tanaman Industri. Kini Menanam Esok Memanen. Proceeding on "Lokakarya Pembangunan Timber Estate. Fakultas Kehutanan IPB bekerja sama dengan Departemen Kehutanan”.

Watson GW. 2007. Associate Insect Biosystematist. Plant Pest Diagnostics Center California. Departement of Food and Agriculture Sacramento USA. http://www.cafa.ca.you/phpps/Entomology/Ent.afa.ca. you/phpps/Entomology/Ent.

Yang S, Sanchun Y. 1997. The conifer woolly aphid (Adelgidae) in China. Journal of Forestry Research 8 (1):30-33. http://dx.doi.org/10.1007/BF02864936 